\title{
PENGEMBANGAN MEDIA E-LEARNING BERBASIS MOODLE SEBAGAI SUPLEMEN PEMBELAJARAN GEOGRAFI PADA MATERI MITIGASI BENCANA ALAM
}

\author{
Raffi Mariezki ${ }^{1}$, Erna Juita ${ }^{2}$, Momon Dt Tanamir ${ }^{3}$ \\ ${ }^{123}$ Pendidikan Geografi, STKIP PGRI Sumatera Barat J1. Gn. Pangilun, Gn. Pangilun, Padang, 25111, Indonesia
}

\begin{tabular}{ll}
\hline INFO ARTIKEL & ABSTRACT \\
\hline Status artikel: & This study aims to analyze the feasibility and practicality of moodle-based E- \\
Diterima: $24-06-2021$ & learning as supplement to learning geography in natural disaster mitigation \\
Disetujui: 02-09-2021 & materials. This type of research is research and development of the four d model, \\
namely: Define, Design, Development, Desiminate. The research subjects of SMA N & 3 Padang class XI IPS. Moodle-based E-learning development includes validation of \\
Tersedia online: $29-09-2021$ & media, education and language experts. The validation data were processed using the \\
Media, Moodle; Suplemen; & interclass correlation coefficient and the results obtained were 0.957. If the value is \\
more than 0.5, it can be concluded that the level of validation is adequate. & Measurement of the feasibility of the media is obtained from data processing using \\
Penulis korespondensi: & Microsoft Excel so that a total score of 282 is obtained with a mean of 4.90 and a \\
Raffi Mariezki & percentage of $98 \%$ with a very good predicate. The practicality test of moodle-based \\
Pendidikan Geografi, & E-learning media was based on questionnaire data and obtained a total score of 4077 \\
STKIP PGRI Sumatera Barat, Padang, & with a mean of 4.1 and a percentage of $82 \%$ with the very practical category. \\
Indonesia. &
\end{tabular}

Email:raffimariezki@gmail.com

DOI: $10.34312 /$ jgej.v2i2.11043

Copyright $(9) 2021$ The Author(s)

\begin{abstract}
ABSTRAK
Penelitian ini bertujuan untuk menganalisis pengembangan kelayakan dan praktikalitas E-learning berbasis moodle sebagai suplemen pembelajaran geografi pada materi mitigasi bencana alam. Jenis penelitian adalah penelitian dan pengembangan model four $d$ yaitu: Define, Design, Develovment,Desiminate. Subjek penelitian siswa SMA N 3 Padang kelas XI IPS. Pengembangan E-learning berbasis moodle meliputi validasi para ahli media,pendidikan dan bahasa. Data validasi diolah dengan spss interclass coefisien corelation dan diperoleh hasil 0,957. Hasil penelitian menunjukkan bahwa media memadai atau valid unutk dikembangkan. Pengukuran kelayakan media diperoleh dari pengolahan data menggunakan Ms Excell sehingga diperoleh total skor 282 dengan mean 4,90 dan persentase $98 \%$ dengan predikat sangat baik. Uji praktikalitas media E-learning berbasis moodle berdasarkan data angket dan diperoleh hasil total skor 4077 dengan mean 4,1 dan persentase $82 \%$ dengan kategori sangat praktis.
\end{abstract}

This open access article is distributed under a Creative Commons Attribution-NonCommercial (CC-BY-NC) 4.0 International License

\section{PENDAHULUAN}

Banyak pemikiran dan inovasi yang mulai dikembangkan untuk mengimbangi pesatnya perkembangan teknologi informasi yang ada, salah satunya dalam sistem pembelajaran. Berkembangnya ilmu sains dan teknologi memicu perkembangan teknologi di dunia pendidikan indonesia. Teknologi informasi merupakan alat bantu dalam menyelesaikan permasalahan yang dihadapi manusia berupa sarana dan prasarana sistem dan metode untuk memperoleh, mengirimkan, mengolah, menafsirkan, menyimpan, meng-organisasikan dan menggunakan data secara bermakna (Nasir, 2013).

Pembelajaran dapat diartikan sebagai proses internalisasi ilmu pengetahuan yang terjadi di dalam kelas yang melibatkan guru dan siswa dibantu dengan media, alat, metode, dan bahan (Syarifudin, 2020). Media pembelajaran yang digunakan oleh guru belum sepenuhnya memanfaatkan teknologi (Bouato et al., 2020). Oleh karena itu metode yang muncul karena pesatnya perkembangan teknologi informasi adalah penggunaan media pembelajaran yang mampu memberikan pengalaman belajar yang berbeda dari proses belajar 
mengajar konvensional. Guru bidang studi geografi, diharapkan dapat memanfaatkan media website dalam pembelajaran. Media pembelajaran yang dapat diakses dimana saja menggunakan gadget dengan melalui internet adalah media pembelajaran dengan bentuk website E-learning yang memberikan berbagai macam variasi penyampaian materi pembelajaran yang dapat diakses siswa secara mandiri.

Media merupakan komponen atau alat yang urgen untuk mendukung proses komunikasi dalam kegiatan pembelajaran. Peran media sebagai sarana atau perangkat yang fungsinya sebagai perantara dalam suatu proses (Permatasari \& Hardiyan, 2018). Jadi berdasarkan pengertian tersebut media pembelajaran merupakan segala benda yang memiliki dan dapat menyalurkan serta menyampaikan informasi, tidak hanya alat peraga, software atau platform pembelajaran tetapi termasuk manusia sebagai objek informasi dan segala kegiatan pembelajaran seperti diskusi, praktek yang menambah wawasan keterampilan dan merubah karakter siswa menjadi lebih baik.

Media pembelajaran dikatakan memiliki fungsi efektif ketika media tersebut dapat membangkitkan minat peserta didik dan motivasi peserta didik untuk aktif dalam mengikuti dan menyimak pembelajaran. (Mansyur, 2020). Sejalan dengan pernyataan diatas bahwa media pembelajaran memiliki kedudukan sangat penting. Penggunaan media pembelajaran harus dipilih dengan baik dan tepat agar dapat mendukung suasana dan kegiatan belajar mengajar (Otoluwa et al., 2019). Disisi lain pandemi merebak keseluruh penjuru indonesia yang menyebabkan berhentinya proses kegiatan belajar mengajar tatap muka di sekolah, kegiatan belajar mengajar selama pendemi harus dilakukan secara online atau daring. Efek dari pandemi covid-19 telah mengubah pandangan terhadap jalannya pendidikan dan pembelajaran di dunia, menghentikan sistem pendidikan dan pembelajaran yang berlangsung secara normal selama ini melalui tatap muka di sekolah. Negara-negara di seluruh penjuru dunia berjibaku untuk mencegahan penularan covid-19 sehingga aktivitas di luar rumah dan perkantoran, termasuk sekolah dinonaktifkan untuk beberapa waktu yang belum bisa ditentukan.

Krisis yang diakibatkan oleh pandemi covid-19 memaksa semua komponen pendidikan menginovasi pembelajaran menjadi pembelajaran jarak jauh atau pembelajaran daring (pembelajaran dalam jaringan). Hal tersebut dimaksudkan supaya proses pembelajaran tidak terhenti di tengah pandemi covid-19. Salah satu model pembelajaran yang adaptif dengan situasi pandemi ini ialah pembelajaran daring untuk meminimalisir penyebaran virus covid-19, karena dengan membatasi interaksi dan kontak langsung sesama siswa dapat meminimalisir penyebaran covid-19. Sistem dan komponen pembelajaran berbasis elektronik atau sering dikenal sebagai E-learning. E-learning sistem pembelajaran yang menggunakan media internet atau media jaringan komputer lain untuk mendistribusikan bahan pembelajaran (Liu, S. H., Liao \& Pratt, 2009). Elearning sebuah inovasi agar sistem pembelajaran dapat terus berlangsung dan lebih terbuka dengan berbagai metode seperti mengorganisir, merumuskan serta menciptakan pengalaman belajar yang lebih efisien.

Berdasarkan wawancara pada tanggal 24 maret 2021 dengan salah satu guru mata pelajaran geografi penulis menemukan beberapa masalah, yakni penggunaan media pembelajaran geografi masih konvensional, sistem pembelajaran masih satu arah berusat pada guru. Kemudian sebagian peserta didik dilihat pasif dalam mengikuti pembelajaran dengan media pembelajaran yang digunakan. Hal tersebut mengindikasikan bahwa peserta didik dan tenaga pendidik membutuhkan media atau produk pembelajaran terbaru, ditambah lagi dalam situasi pandemi guru sangat sulit dalam menarik minat siswa untuk belajar secara konsisten, siswa banyak yang terkesan setengah hati dalam mengikuti proses pembelajaran dan semangat belajar yang semakin menurun. Selain itu, dengan mewawancarai beberapa peserta didik tentang proses kegiatan belajar selama pandemi, hasil dari mewawancarai peserta didik tersebut bahwa peserta didik kesulitan untuk memahami pembelajaran geografi karena harus adaa pemahaman secara mendalam terhadap materi. Selama pandemi berlangsung kegiatan belajar banyak menggunakan media berupa elekronik modul(e-modul) dan LKPD yang diupload tiap minggu di Whatsapp grup dan google classroom.

E-learning berbasis moodle menyajikan tools yang mendukung kegiatan belajar mengajar selama pandemi dan sangat mudah diakses oleh pendidik dengan gawai yang terkoneksi jaringan Internet serta menggunakan jaringan intranet, LAN, dan sejenisnya. Moodle bersifat cecourse management system (CMC), learning management system (LMS) atau virtual learning environment (VLE), Moodle merupakan sebuah platform learning yang mampu mengkonversikan media pembelajaran menjadi web (Herayanti et al., 2017). Manfaat dari penggunaan moodle secara online sangat penting mampu mengatasi keterbatasan jarak dan waktu antara guru dengan siswa.

Moodle platform berbasis web untuk management kelas online, jika dibandingkan dengan media online lain seperti classroom dan edmodo. Moodle memiliki tools atau fitur yang lebih lengkap, moodle dapat 
digunakan sebagai media untuk merancang materi pembelajaran lebih menarik, tools kuis, modul elektronik, video pembelajaran, games test, dan penilaian secara otomatis. Kedudukan platform learning moodle dalam pembelajaran sangat mengefisienkan kegiatan pembelajaran. Hal tersebut dapat direalisasikan ketika moodle dikembangkan, dan ketika guru dan siswa melakukan aktivitas belajar mengajar secara online berbasis web. Platform ini mampu memicu rasa ingin tahu siswa untuk bergabung kedalam ruang kelas digital dan mengakses semua fitur-fitur yang didalam terdapat materi-materi pembelajaran yang dikema kreatif dan menyenangkan. Berangkat dari masalah pada paragraf sebelumnya, maka penulis berusaha membuat media atau produk pembelajaran E-learning berbasis moodle sebagai alternatif yang mampu menyajikan desain pembelajaran geografi yang lebih menarik dan dapat diakses dimana saja oleh peserta didik baik disekolah manapun dirumah, sehingga peserta didik lebih termotivasi untuk memahami pembelajaran geografi secara mendalam.

\section{Metode}

Penelitian ini menggunakan metode penelitian dan pengembangan atau sering dikenal dengan research and development. Pengembangan merupakan bagian dari proses atau tahap dalam mengembangkan serta mevalidasi media atau produk yang akan dikembangkan dilingkungan pendidikan dan pengajaran. Penelitian pengembangan bagian dari ikhtiar menghasilkan media atau produk pembelajaran yang mampu memberikan solusi dan mengatasi masalah di lingkungan pendidikan dan pengajaran (Permatasari, 2018).

Penelitian ini melibatkan siswa - siswa SMA N 3 Padang kelas XI IPS. Tujuan utama dari penelitian ini adalah mengembangkan media pembelajaran yang berbasis E-learning untuk mata pelajaran geografi pada materi mitigasi bencana alam. Penelitian ini dilakukan menggunakan prosedur penelitian pengembangan yang mengacu pada model pengembangan perangkat pembelajaran yang dikembangkan oleh S.thiagarajan, Dorothy S. Semmel, dan Melvyn I. Semmel atau dikenal dengan model four d yang terdiri dari 4 tahap yaitu:1.Pendefinisian(define), 2.Perancangan (design), 3.Pengembangan (development), dan 4.penyebaran (disseminate). Namun dalam penelitian ini dilakukan hanya sampai tahap development (pengembangan), dikarenakan tujuan penelitian telah tercapai pada tahap development. Berikut peneliti jabarkan prosedur pengembangan penelitian (Sri, 2020).

\subsection{Tahap Pendefinisian (Define)}

Tahapan ini untuk membatasi materi kemudian menyesuaikan dengan syarat - syarat dan tujuan pembelajaran, berikut langkah - langkahnya:

\section{a. Analisis awal akhir}

Analisis ini merupakan proses analisis kompetensi dasar materi yang digunakan serta analisis kurikulum yang digunakan. Analisis kurikulum sangat penting agar seluruh perangkat pembelajaran dapat bersinergi dan menjadi sistem yang saling terhubung untuk mencapai tujuan pembelajaran.

b. Analisis Peserta didik

Analisis peserta didik adalah proses menggali lebih dalam kondisi dari spiritual peserta didik, karakteristik kemudian latar belakang pengetahuan, dan tingkat laju perkembangan kognitif, afektif, dan psikomotor peserta didik.

\section{c. Analisis Materi}

Tahap analisis materi merupakan proses identifikasi indikator materi yang diajarkan kepada peserta didik, dikonsep melalui peta konsep secara sistematis agar memudahkan peserta didik dalam memahami materi.

\section{d. Tujuan Pembelajaran}

Penyusunan tujuan pembelajaran atau indikator pencapaian hasil belajar didasarkan pada kompetensi dasar dan indikator yang tercantum dalam Kurikulum 2013 menjadi acuan dasar dalam menentukan dan menyusun indikator dan kompetensi pembelajaran.

\section{e. Tahap Perancangan (Desain)}

Media atau produk yang dikembangkan adalah e-learning dengan aplikasi moodle diprogram berdasarkan analisis materi, indikator dan kompetensi pembelajaran.

\section{f. Tahap Pengembangan (Develop)}

Pada tahap ini berdasarkan masukan dan komentar dari para ahli serta data hasil uji coba lahir bentuk akhir media atau produk pembelajaran setelah melalui beberapa kali revisi. Pada tahap ini langkah langkah yang dilalui adalah sebagai berikut:

Validasi Ahli 
Kevalidan media atau produk uji coba ditentukan berdasarkan argumen teoritis para praktisi atau para ahli. Pada penelitian ini peneliti memilih validator terdiri dari beberapa ahli yaitu ahli bahasa, media dan pendidikan serta ahli geografi. Kemudian validator memvalidasi media terlebih dahulu pada tahap perancangan. Masukan dan saran validator merupakan pedoman dari revisi media atau peoduk pembelajaran.

\section{Uji coba terbatas}

Setelah revisi media atau produk pembelajaran maka produk perlu diuji cobakan. Uji coba produk pembelajaran dilakukan pada satu kelas untuk menghimpun masukkan dari peserta didik dan tenaga pendidik di lingkungan belajar terhadap media atau produk pembelajaran yang telah digunakan. Uji coba dilakukan pada kelas XI yang berjumlah 30 orang. Pelaksanaan uji coba didampingi oleh guru mata pelajaran geografi.

\section{Tahap Penyebaran (Disseminate)}

Pada tahapan ini penggunaan media atau produk pembelajaran yang dikembangkan dan diuji cobakan pada parameter yang lebih besar. Tahap penyebaran merupakan tahap uji keefektifan media atau produk pembelajaran pada sekolah berbeda. Tetapi, pada penelitian ini banyaknya keterbatasan pada peneliti dari segi biaya maka peneliti hanya melakukan penyebaran di sekolah tempat penelitian.

\section{Subjek Uji Coba}

Peneliti memilih kelas XI IPS 1 dan XI IPS 2 SMAN 3 Padang Sumatera Barat tahun ajaran 2020/2021 sebagai objek uji coba pada penelitian ini. Kemudian dalam penelitian ini guru dan peserta didik ditunjuk sebagai reponden. Untuk lebih jelas mengenai jumlah subjek uji coba pada penelitian pengembangan ini akan dijabarkan pada tabel 1.

Tabel 1. Subjek Uji coba

\begin{tabular}{lll}
\hline No & Kelas & Jumlah Siswa \\
\hline 1 & XI IPS 1 & 33 \\
\hline 2 & XI IPS 2 & 35 \\
\hline
\end{tabular}

\subsection{Jenis Data}

Data primer merupakan data yang diperoleh langsung dari responden yang menjadi sasaran penelitian(Indah, 2020). Dalam penelitian pengembangan ini peneliti memperoleh data primer berdasarkan observasi kemudian data dari pengisian kuesioner oleh responden. Data sekunder adalah sumber data yang diperoleh oleh pengumpul data secara tidak langsung. Data sekunder di peroleh dari guru mata pelajaran geografi kelas XI SMAN 3 Padang.

Pengembangan media atau produk E-learning berbasis Moodle akan diselesaikan sesuai dengan prosedur pengembangan model four $d$ terdiri dari 4 tahapan, pendefinisian, perancangan, pengembangan, dan penyebaran (Puspita, 2017). Kemudian (Fadriati, 2017) menjelaskan Teknik analisis antar rater umumnya menggunakan koefisien korelasi intrakelas untuk analisis validasi instrumen penelitian rumus ICC (i) :

$$
I C C=\frac{\sigma_{S}^{2}}{\sigma_{S}^{2}+\sigma_{o}^{2}+\sigma_{e}^{2}}
$$

varians $(\sigma 2)=$ ukuran variasi,

subskrip s = subjek (pasien);

$\mathrm{o}=$ pengamat;

$\mathrm{e}=$ random error. 
Bila variasi pengamat diasumsikan fixed, maka variasi pengamat tidak diperhitungkan dalam variasi total (Fadriati, 2017).

\subsection{Analisis kelayakan}

Menilai kelayakan media atau produk pembelajaran untuk diterapkan pada mata pelajaran geografi kelas XI di SMAN 3 Padang. Untuk menghitung bobot masing-masing tanggapan serta menghitung skor rataratanya bisa menggunakan formula Nilai kelayakan angket tiap aspek (ii) (Damayanti, 2018).

Ket :

$$
\mathrm{Xi}=\frac{\sum s}{S_{\max }} \times 100 \%
$$

$S_{\max }=$ Skor Maksimal

$\sum \mathrm{S}=$ Jumlah skor

$\mathrm{Xi}=$ Nilai kelayakan angket tiap aspek

Berikut kriteria menurut Arikunto untuk kategori kelayakan dalam (Sukardiyono, 2017) tabel 2.

Tabel 2. Tingkat kelayakan

\begin{tabular}{cl}
\hline Skor Dalam Persen & Kategori \\
\hline$<21 \%$ & Sangat tidak layak \\
\hline $21-40 \%$ & Tidak layak \\
\hline $41-60 \%$ & Cukup layak \\
\hline $61-80 \%$ & Layak \\
\hline $81-100 \%$ & Sangat layak \\
\hline
\end{tabular}

Sumber : (Sukardiyono, 2017)

\subsection{Analisis Praktikalitas}

Produk pembelajaran dikategorikan praktis jika peserta didik mampu menggunakan dan memberdayakan media atau produk pembelajaran tersebut dalam kegiatan belajar mengajar secara praktis dan efisien. Data analisis praktikalitas didapat dari instrumen atau alat pengamatan keterlaksanaan rencana pelaksanaan pembelajaran, kuesioner tenaga pendidik dan peserta didik terhadap media atau produk E-learning yang dikembangkan. Pemberian nilai praktikalitas mengacu atau berpedoman rumus jumlah skor yang di peroleh dibagi jumlah skor tertinggi dikalikan 100\% (iii) :

$$
\frac{\text { Jumlah Skor yang diperoleh }}{\text { Jumlah skor tertinggi }} \times 100 \%
$$

Setelah persentase diperoleh, dilakukan pengelompokkan sesuai kriteria tabel 3 :

Tabel 3. Tingkat praktikalitas

\begin{tabular}{cc}
\hline Interval & Kategori \\
\hline $86 \%-100 \%$ & sangat praktis \\
\hline $76 \%-85 \%$ & Praktis \\
\hline $60 \%-75 \%$ & cukup praktis \\
\hline$\leq 54 \%$ & sangat tidak praktis \\
\hline
\end{tabular}

(Sumber: Lestari, 2018)

\section{Hasil dan Pembahasan}

Media atau produk E-learning geografi berbasis platform moodle yang berupa website adalah produk dari penelitian dan pengembangan ini. Pembuatan E-learning pada materi mitigasi bencana alam terdiri kursus atau kelas dan materinya didesign semenarik mungkin menggunak fitur-fitur yang ada di modle, dapat berupa e-modul, video, poster dan quiz. Pengembangan media atau produk E-learning ini terdiri dari 
beberapa tahapan, tahap definisi, tahap design tahap mengembangkan. Berdasarkan pengolahan dan perhitungan maka diperoleh hasil pengembangan sebagai berikut:

Pada tahap design produk peneliti melakukan instalasi webserver, aplikasi moodle di pc yang peneliti gunakan,disini peneliti menggunakan xampp versi 5.6.40-0-VC11 dan moodle versi 2.8.0 selanjutnya instalasi path, basis data, plugin konten kemudian membuat user admin, header name E-learning. Selanjutnya setelah instalasi selesai yaitu membuat kategori dan kursus. Pada kursus dibuat konten - konten pembelajaran berupa materi pembelajaran berupa e-modul, forum chat diskusi, video referensi, poster poster pembelajaran dan quiz, tahap terakhir hosting dan membuat domain serta enroll user dengan membuatkan user name dan passwors untuk login di E-learning berbasis moodle moodle. Adapun nama domain yang digunakan adalah http://192.168.43.116/moodle/.

Pada tahap validasi media, produk yang dikembangkan merupakan media pembelajaran atau produk pembelajaran E-learning berbasis atau menggunakan platform moodle yang akan diukur tingkat kevalidan dari hasil penilaian validator. Penilaian pertama dilakukan oleh ibu Loli setriani,M,Pd sebagai dosen pakar atau ahli media, Bapak Armet M.Pd sebagai dosen pakar atau ahli bahasa, dan Bapak Slamet Rianto, M.Pd sebagai dosen pakar atau ahli pendidikan. pengolahan data menggunakan aplikasi spss dan data hasil penilaian media aau produk pembelajaran yang dikembangkan disajikan pada tabel. Maka setelah dilakukan pengolahan data pada spss diproleh hasil validasi dari ahli atau pakar media, ahli bahasa, dan ahli pendidikan seperti peneliti dijabarkan pada tabel 4:

Tabel 4. Interaclass coefitien corelation

\begin{tabular}{cccc}
\hline Data & Alpha Cronbach's & ICC & Keterangan \\
\hline Validasi & 0.985 & 0.957 & Memadai \\
\hline
\end{tabular}

Tabel 4 menggambarkan nilai hasil pengolahan data validasi dari para ahli yaitu nilai alpha cronbach's didapati 0.985 dan nilai Interaclass coefitien corelation (ICC) didapati 0.95. Berdasarkan standar error minimum nilai interclass coefition corelation apabila nilai yang didapati lebih dari 0.50 maka dapat diambil kesimpulan tingkat validasi nya adalah memadai. Dengan demikian berarti produk atau media E-learning sudah valid menurut pakar, sehingga bisa dilanjutkan ketahap berikutnya.

Pada tahap mengembangkan media atau produk dilakukan pengembangan pada tampilan-tampilan media atau produk E-learning berbasis platform moodle. Gambar 1 merupakan gambar dari tampilan media pembelajaran atau produk pembelajaran E-learning berbasis paltform moodle yang dikembangkan:

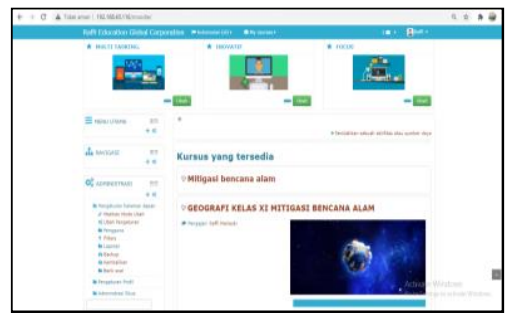

(1) Tampilan Dashboard e-Learning

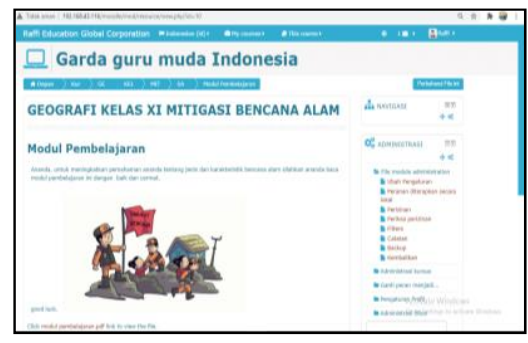

(3) Tampilan panel materi/modul

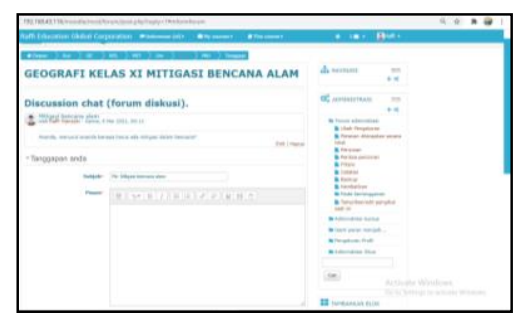

(2) Tampilan forum chat

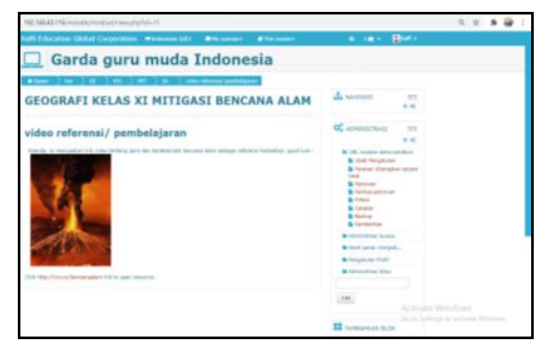

(4)Tampilan panel video referensi

Gambar 1 Tampilan Awal E-Learning 


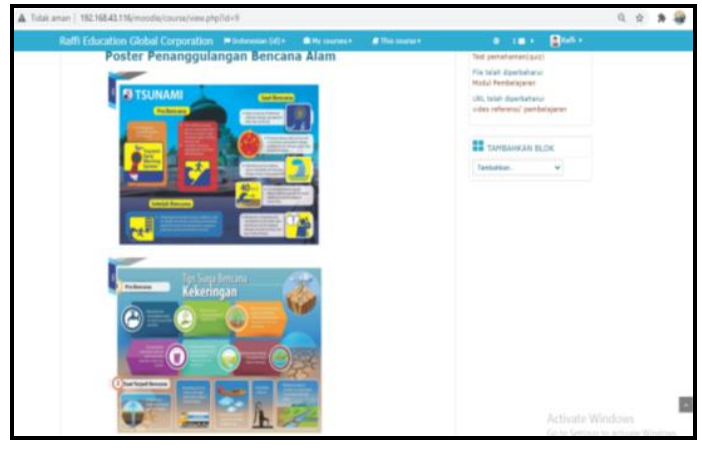

(5)Tampilan poster pembelajaran

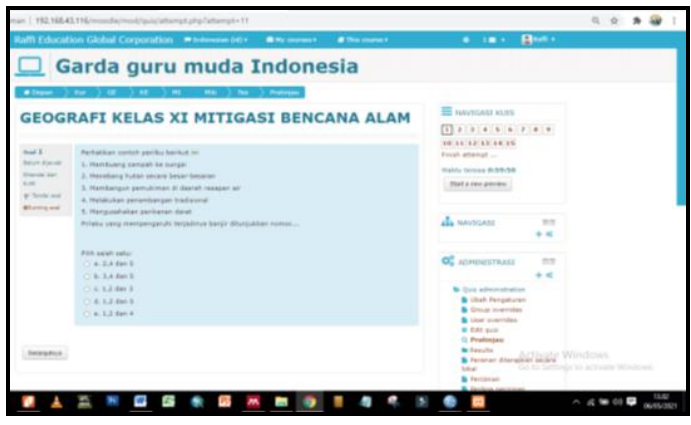

(6) Tampilan panel quiz

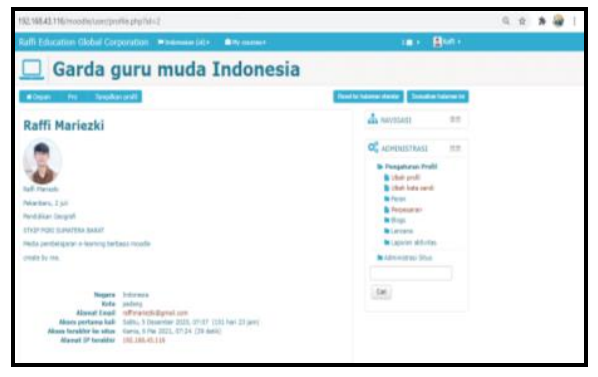

(7) Tampilan profil admin

Gambar 2. Tampilan Isi Atau Produk E-Learning Berbasis Platform Moodle

Tahap selanjutnya uji kelayakan media pembelajaran, kelayakan produk yang dikembangkan dilkakukan uji kelayakan media menggunakan angket, hasil yang didapatkan tertera pada tabel 5.

Tabel 5. Kesimpulan Indikator

\begin{tabular}{llllll}
\hline No & Indikator & $\sum$ & mean & $\%$ & Keterangan \\
\hline 1 & Aspek Relevansi materi & 50 & 5 & $100 \%$ & Sangat Baik \\
\hline 2 & Aspek Pengorganisasian Materi & 126 & 4,85 & $97 \%$ & Sangat Baik \\
\hline 3 & Aspek Bahasa & 20 & 5 & $100 \%$ & Sangat Baik \\
\hline 4 & $\begin{array}{l}\text { Aspek Efek bagi strategi } \\
\text { pembelajaran }\end{array}$ & 46 & 4,6 & $92 \%$ & Sangat Baik \\
\hline 5 & Aspek Rekayasa perangkat lunak & 20 & 5 & $100 \%$ & Sangat Baik \\
\hline 6 & Aspek Tampilan Visual & 20 & 5 & $100 \%$ & Sangat Baik \\
\hline & Rata-rata & 82 & 4,90 & $98 \%$ & sangat Baik \\
\hline
\end{tabular}

Dari tampilan tabel 5 kesimpulan indikator, diperoleh dari responden menggunakan angket kemudian data yang diperoleh dari angket dioperasikan menggunakan formula microsoft excel. Maka didapat data ratarata tingkat pencapaian responden perindikator adalah sebesar $98 \%$ artinya "Sangat Baik". Berarti media atau produk yang dikembangkan pada penelitian ini memiliki tingkat kelayakan yang sangat layak untuk membantu proses pembelajaran geografi. Moodle dapat dengan mudah dipakai (Surjono, 2013).

Tahap selanjutnya uji praktikalitas media pembelajaran, pada tahap ini diperlukan uji praktikalitas sebuah produk media pembelajaran untuk melihat tingkat kepraktisan media yang dikembangkan,. Seperti yang tertera pada tabel kesimpulan indikator uji praktikalitas dibawah ini. 
Tabel 6. Kesimpulan Indikator

\begin{tabular}{llllll}
\hline No & Indikator & $\sum$ & mean & $\%$ & Keterangan \\
\hline 1 & Aspek Relevansi materi & 421 & 4,01 & $80 \%$ & Praktis \\
\hline 2 & Aspek Pengorganisasian materi & 1543 & 4,14 & $83 \%$ & Sangat Praktis \\
\hline 3 & Aspek Bahasa & 270 & 3,86 & $77 \%$ & Praktis \\
\hline 4 & $\begin{array}{l}\text { Aspek Efek bagi strategi } \\
\text { pembelajaran }\end{array}$ & 707 & 4,04 & $81 \%$ & Sangat Praktis \\
\hline 5 & Aspek Rekayasa perangkat lunak & 561 & 4,54 & $91 \%$ & Sangat Praktis \\
\hline 6 & Aspek Tampilan visual & 575 & 4,10 & $82 \%$ & Sangat Praktis \\
\hline 7 & Total & 4077 & & & \\
\hline & Rata-rata & 4,12 & $82 \%$ & Sangat Praktis \\
\hline
\end{tabular}

Tabel 6 menggambarkan tingkat pencapaian responden yang terdiri dari 35 orang responden yang kemudian diukur menggunakan angket. Maka dapat diambil kesimpulan rata-rata tingkat pencapaian responden perindikator adalah sebesar $82 \%$ artinya "sangat praktis". Dengan demikian berarti media atau produk sangat praktis digunakan. dapat membantu peserta didik lebih mudah untuk mengoperasikan produk yang dikembangkan dalam memahami materi geografi.

\section{Kesimpulan}

Berdasarkan penelitian dan pembahasan yang sudah dijabarkan diatas, didapat beberapa kesimpulan sebagai berikut: Pengembangan media atau produk pembelajaran E-learning berbasis moodle ini meliputi validasi dari para ahli pakar yaitu ahli pakar media, ahli pakar pendidikan, dan ahli pakar bahasa. Sehingga didapat data validasi produk kemudian diolah dengan rumus Interaclass Coefitien Corelation (ICC) dibantu pengolahan menggunakan aplikasi SPSS maka diperoleh hasilnya adalah 0.957. Nilai lebih dari 0.50 artinya tingkat validasi nya adalah memadai. Media atau produk pembelajaran E-learning berbasis platform moodle dinyatakan sangat layak setelah dianalisis pengolahan data menggunakan Microsoft Excel sehingga diperoleh hasil total skor 282 dengan tingkat mean 4,90 dan tingkat persentase $98 \%$ dengan predikat "Sangat Baik". Media pembelajaran E-learning berbasis moodle dinyatakan praktis setelah dilakukan pengolahan data hasil penelitian yang diperoleh dari angket, dan dilakukan uji praktikalitas sehingga diperoleh hasil total skor 4077 dengan tingkat mean 4,15 dan persentase senilai $82 \%$ artinya "Sangat Praktis". Rekomendasi dari penelitian ini selanjutnya adalah pelaksanaan penyebarluasan produk penelitian berupa media pembelajaran E-learning berbasis moodle hendaknya dilakukan di SMA/MA yang lebih banyak dan harus lebih memperhatikan penggunaan server, hosting berbayar atau premium dalam pengembangan media, agar memiliki daya akses yang lebih optimal.

\section{Referensi}

Bouato, Y., Lihawa, F., \& Rusiyah, R. (2020). Pengembangan Media Pembelajaran Berbasis Sparkol Videoscribe Yang Diintegrasikan Dengan Wondershare Filmora Pada Mata Pelajaran Geografi Materi Mitigasi Bencana Alam. Jambura Geo Education Journal, 1(2), 71-79. https://doi.org/10.34312/jgej.v1i2.7131

Damayanti, A. E., Syafei, I., Komikesari, H., \& Rahayu, R. (2018). Kelayakan Media Pembelajaran Fisika Berupa Buku Saku Berbasis Android. 01(1), 63-70.

Fadriati, F. (2017). a Model of Discovery Learning Based - Text Book of Character and Islamic Education: an Accuracy Analysis of Student Book in Elementary School. Ta'dib, 20(2), 188. https://doi.org/10.31958/jt.v20i2.1019

Herayanti, L., Fuaddunnazmi, M., \& Habibi, H. (2017). Pengembangan Media Pembelajaran Berbasis Moodle pada Mata Kuliah Fisika Dasar. Jurnal Pendidikan Fisika Dan Teknologi, 1(3), 205. https://doi.org/10.29303/jpft.v1i3.260

Indah Azhari, S. R., Junaid, A., \& Tjan, J. S. (2020). Pengaruh Kompetensi, Independensi, Dan Profesionalisme Auditor Terhadap Kualitas Audit Dengan Etika Auditor Sebagai Variabel Moderasi. 
Invoice : Jurnal Ilmu Akuntansi, 2(2), 139-184. https://doi.org/10.26618/inv.v2i2.4116

Lestari, L., Alberida, H., \& Rahmi, Y. L. (2018). Validitas dan Praktikalitas Lembar Kerja Peserta Didik (LKPD) Materi Kingdom Plantae Berbasis Pendekatan Saintifik untuk Peserta Didik Kelas X SMA/MA. Jurnal Eksakta Pendidikan (Jep), 2(2), 170. https://doi.org/10.24036/jep/vol2-iss2/245

Liu, S. H., Liao, H. L., \& Pratt, J. A. (2009). (2009). Impact of media richness and flow on e-learning technology acceptance. Computers \& Education, 5(2), 599-607.

Mansyur, A. R. (2020). Dampak covid-19 terhadap dinamika pembelajaran di indonesia. Education and Learning Journal, 1(2), 113-123.

Nasir, M. (2013). Evaluasi Penerimaan Teknologi Informasi Mahasiswa di Palembang Menggunakan Model UTAUT. Seminar Nasional Aplikasi Teknologi Informasi (SNATI), 1(1), 15-2013.

Otoluwa, Y., Eraku, S., \& Yusuf, D. (2019). Pengembangan Media Pembelajaran Berbasis Lectora Inspire Yang Diintegrasikan Dengan Camtasia Studio Pada Mata Pelajaran Geografi Materi Sistem Informasi Geografi. JAMBURA GEO EDUCATION JOURNAL, 1(1), 01-08. https://doi.org/10.34312/jgej.v1i1.4041

Permatasari, I., \& Hardiyan, H. (2018). Pengaruh E-Learning Sebagai Media Pelatihan dan Pengembangan Terhadap Kinerja Karyawan BCA KCU Tangerang. Jurnal Sisfokom (Sistem Informasi Dan Komputer), 7(1).

Puspita. (2017). Pengembangan Media Pembelajaran Booklet Pada Materi Sistem Imun Terhadap hasil Belajar Siswa kelas XI SMAN 8 Pontianak. 4(1), 64-73.

Sukardiyono, I. E. \& T. (2017). Uji Kelayakan Media Pembelajaran Interaktif Pada Mata Pelajaran Administrasi Server. Elinvo, Vol.2 No., 205-210.

Surjono, H. D. (2013). Membangun Course E-Learning Berbasis Moodle. Membangun Course E-Learning Berbasis Moodle, Part II, 1-196.

Syarifudin, A. S. (2020). Impelementasi pembelajaran daring untuk meningkatkan mutu pendidikan sebagai dampak diterapkannya social distancing. Urnal Pendidikan Bahasa Dan Sastra Indonesia Metalingua, $5(1), 31-34$. 